Ekonomia - Wroclaw Economic Review 23/1 (2017)

Acta Universitatis Wratislaviensis

No 3754

DOI: $10.19195 / 2084-4093.23 .1 .4$

\title{
Piotr Rogala
}

Uniwersytet Ekonomiczny we Wrocławiu

piotr.rogala@ue.wroc.pl

\section{Pomiar subiektywnej jakości życia na poziomie lokalnym - studium przypadku}

\author{
JEL Classification: H75, M10
}

Keywords: subjective quality of life, quality of life evaluation, local and regional development

\begin{abstract}
Measuring the subjective quality of life at the local level - a case study

The paper concerns a project which was carried out in 2015. The main aim of the project was to develop a method, and then to measure the subjective quality of life of the inhabitants of 12 municipalities of the province of Lower Silesia. The questionnaires provided responses from 671 respondents who rated their satisfaction with life and the importance and satisfaction with various components of quality of life. On this basis the possibility of using measurement of subjective quality of life in the creation and evaluation of local and regional development programs was specified.
\end{abstract}

\section{Wprowadzenie}

Termin ,jakość życia” zyskuje coraz większą popularność w administracji samorządowej. Szczególnie często wykorzystywany jest na etapie formułowania celów w dokumentach programujących rozwój jednostek samorządu terytorialnego (tj. województw, powiatów oraz gmin). Na przykład w „Strategii rozwoju województwa dolnośląskiego 2020” jako nadrzędny cel rozwoju wskazano „nowoczesną gospodarkę i wysoką jakość życia w atrakcyjnym środowisku" (Strategia rozwoju..., 2014, s. 24). Natomiast w „Strategii rozwoju Legnicy 2015-2020 plus” jednym z pięciu celów strategicznych jest „Poprawa jakości i warunków życia legniczan” (Urząd Miasta Legnicy, 2015, s. 143). Wykorzystywanie koncepcji jakości życia $\mathrm{w}$ tym zakresie jest zgodne $\mathrm{z}$ postulatami formułowanymi w literaturze przedmiotu (por. Kusterka-Jefmańska, 2010, s. 115-123). Zwykle jednak zainteresowanie jakością życia ogranicza się do sformułowania celów. Można nawet odnieść wra- 
żenie, że termin ten wpisywany jest do dokumentów planistycznych bez głębszego namysłu, jako modne i dobrze brzmiące hasło. Minimalnym działaniem, którego należy oczekiwać od władz lokalnych i regionalnych wskazujących jakość życia jako cel rozwoju, jest wprowadzenie rozwiązań umożliwiających cykliczną ocenę poziomu jakości życia mieszkańców danego obszaru. Niewiele polskich jednostek samorządu terytorialnego podjęło jednak tego typu działania. Znalazły się wśród nich przede wszystkim duże miasta, takie jak Poznań oraz Kraków. Najmniejszym zainteresowaniem pomiar jakości życia cieszy się natomiast w gminach wiejskich.

Celem artykułu jest charakterystyka podejścia wypracowanego podczas badania subiektywnej jakości życia mieszkańców dwunastu gmin województwa dolnośląskiego oraz prezentacja wybranych wyników uzyskanych podczas tego badania i na tej podstawie dostarczenie argumentów potwierdzających tezę, iż badania subiektywnej jakości życia mogą znaleźć praktycznie zastosowanie w zarządzaniu jednostkami samorządu terytorialnego. Ze względu na swój charakter opracowanie może być uznane za studium przypadku (por. Czakon, 2011).

\section{Jakość życia}

Wysiłki podejmowane przez badaczy oraz różnego rodzaju instytucje doprowadziły do pojawienia się wielu równolegle funkcjonujących definicji jakości życia. Ich ogólny sens jest zbliżony, lecz różnią się one między sobą pewnymi szczegółami. Jedna z pierwszych definicji sformułowana została w 1972 roku i mówiła, że jakość życia to satysfakcja z życia oraz poczucie szczęścia. A. Campbell uważał z kolei, że na jakość życia składa się stopień zaspokojenia w określonych z góry dziedzinach życia, do których zaliczył: małżeństwo, życie rodzinne, zdrowie, sąsiadów, znajomych, zajęcia domowe, pracę zawodową, życie w danym kraju, miejsce zamieszkania, czas wolny, warunki mieszkaniowe, wykształcenie i standard życia (Papuć, 2011, s. 142). Wśród najczęściej przytaczanych znajduje się definicja opracowana przez Światową Organizację Zdrowia. Zgodnie z nią jakość życia to postrzeganie przez jednostkę własnej sytuacji życiowej w kontekście uwarunkowań kulturowych i systemu wartości oraz w powiązaniu z jej celami, oczekiwaniami, standardami i zainteresowaniami (Turska, Skowron, 2009, s. 572). Aby uzyskać pełny obraz jakości życia, należy ocenić zarówno jej subiektywny, jak i obiektywny wymiar. Obiektywna jakość życia zbliżona jest znaczeniowo do pojęcia warunków życia (a także poziomu życia), które można opisać jako całokształt obiektywnych warunków, głównie o charakterze infrastrukturalnym w jakich żyje dana społeczność. Wiążą się one głównie z: (1) kondycją materialną, (2) zabezpieczeniem egzystencjalnym i (3) zabezpieczeniem środowiskowym życia jednostek. Pomiar tej jakości dokonywany jest przez wskaźniki występujące najczęściej w formie naturalnych miar natężenia. Obiektywna jakość życia dotyczy zwykle takich zagadnień, jak: sytuacja dochodowa, zasobność materialna, uczestnictwo w kultu- 
rze i wypoczynku, korzystanie z usług służby zdrowia itp. (Jakość życia..., 2008, s. 13). Subiektywna jakość życia związana jest z postrzeganiem własnego życia w ramach określonego systemu wartości i w określonych warunkach społecznych, gospodarczych i politycznych. Wymiar subiektywny obejmuje takie zagadnienia, jak indywidualna ocena stanu zdrowia oraz indywidualna ocena dobrobytu (Borys, Knippschild, 2014, s. 15). Za podstawowy wskaźnik subiektywnej jakości życia przyjmowane jest najczęściej zadowolenie z własnego życia (Rogala, 2014, s. 146).

Mimo że badania jakości życia nie są jeszcze zjawiskiem powszechnym w funkcjonowaniu polskich jednostek samorządu terytorialnego, to można wskazać już kilka przykładów (głównie miast), które takie działania przeprowadziły. Najbogatszymi doświadczeniami w tym zakresie dysponuje Poznań. Pewne działania podejmowane były także w Sopocie, Elblągu, Gliwicach, Jaworznie, Ostrowie Wielkopolskim, Zatorze, Łodzi, Olkuszu, Gdańsku oraz powiecie świdnickim. Analiza porównawcza podejść stosowanych przez te organizacje (Rogala, 2013) wykazała, iż w każdym z tych przypadków zastosowano inną metodę. Różnice dotyczyły m.in. zakresu zagadnień objętych badaniem, skal pomiaru oraz sposobów formułowania pytań. W niektórych przypadkach różnice były duże, a w innych małe. Z całą jednak pewnością stwierdzić można, że nie ma tu powszechnie przyjętego standardu.

\section{Opis przeprowadzonych badań}

Badania subiektywnej jakości życia przeprowadzone zostało z inicjatyw Stowarzyszenia Lokalna Grupa Działania „Kraina Łęgów Odrzańskich”. Wykonawcą projektu zostało Towarzystwo Naukowe „Jakość i Środowisko” z Jeleniej Góry.

Projekt składał się z trzech głównych etapów.

\section{Etap I}

Etap pierwszy polegał na opracowaniu narzędzia badawczego. Na potrzeby badania zaprojektowany został kwestionariusz, który składał się z trzech części.

Pierwsza część koncentrowała się na ocenie zadowolenia z życia oraz ocenie zadowolenia ze stanu każdej z dziewięciu kluczowych dziedzin życia:

1) zdrowia,

2) wykształcenia,

3) bezpieczeństwa publicznego i socjalnego,

4) kultury i rekreacji,

5) sytuacji materialnej i zawodowej,

6) dostępności produktów i usług, a także dostępność komunikacyjnej,

7) środowiska przyrodniczego,

8) relacji z rodziną, znajomymi i sąsiadami oraz

9) zarządzania gminą. 
Do oceny przyjęto pięciostopniową skalę pomiaru, dla której określono następujące punkty skali 1 - bardzo niezadowolony, 2 - niezadowolony, 3 - ani zadowolony, ani niezadowolony, 4 - zadowolony, 5 - bardzo zadowolony.

W ramach każdej z tych dziewięciu dziedzin wyodrębniono konkretne czynniki warunkujące jakości życia, takie jak dostęp do lekarzy podstawowej opieki, funkcjonowanie pogotowia ratunkowego, bezpieczeństwo osobiste, warunki poruszania się własnym środkiem transportu (samochodem, motocyklem). W ankiecie zaprezentowano łącznie czterdzieści jeden takich zagadnień. Respondenci oceniali znaczenie, a także stopień spełnienia oczekiwań (stan) w przypadku każdego z nich. W obu przypadkach korzystali z pięciostopniowej skali. Oceniając wagę zagadnień, mogli wybrać jedną z pięciu proponowanych odpowiedzi, tj. 1 — nieważne lub mało ważne, 2 - raczej ważne, 3 - średnio ważne, 4 - bardzo ważne, 5 - niezbędne. Natomiast przy ocenie stanu dostępne były następujące odpowiedzi: 1 - bardzo źle, 2 - źle, 3 - średnio, 4 - dobrze, 5 - bardzo dobrze.

Druga część kwestionariusza zawierała pytania dotyczące dwóch tematów (1) stanu obecnego i przyszłości danej miejscowości oraz (2) sytuacji zawodowej i dochodów respondentów. W tej części respondenci zostali poproszeni o ustosunkowanie się do 14 stwierdzeń, na przykład:

1. Warunki życia w mojej miejscowości poprawiły się w ciągu ostatnich kilku lat.

2. Chciałbym, aby moje dzieci mieszkały w tej samej miejscowości, w której ja teraz mieszkam.

3. Gdybym żył w dużym mieście, to byłbym szczęśliwszy.

4. Chciałbym zmienić miejsce zatrudnienia.

W przypadku każdego z tych stwierdzeń respondenci mogli wybrać jedną z pięciu odpowiedzi: 1 - zdecydowanie nie, 2 - raczej nie, 3 - ani tak, ani nie, 4 - raczej tak, 5 - zdecydowanie tak.

W trzeciej części kwestionariusza zamieszczono pytania charakteryzujące respondentów. Dotyczyły one płci, wieku, wykształcenia, miejsca zamieszkania, aktywności zawodowej oraz okresu zamieszkiwania na terenie gminy.

\section{Etap II}

Etap drugi stanowiła ankietyzacja. W kwietniu oraz maju 2015 roku przeprowadzano wywiady bezpośrednie $\mathrm{z}$ wykorzystaniem papierowej wersji kwestionariusza ankiety. Badaniem objęci zostali mieszkańcy dwunastu gmin wchodzących w skład „Krainy Łęgów Odrzańskich”, czyli Brzegu Dolnego, Głogowa, Jemielnicy, Malczyc, Miękini, Pęcławia, Prochowic, Rudnej, Ścinawy, Środy Śląskiej, Wińska oraz Wołowa.

Kryteria doboru próby zostały oparte na trzech podstawowych zmiennych wieku, płci oraz miejscu zamieszkania. Przeprowadzono łącznie 712 wywiadów, jednak po ich przeglądzie okazało się, że tylko 671 jest poprawnie wypełnionych. 
Kobiety stanowiły $62 \%$ ogółu próby badawczej. Największy udział w próbie przypadł ankietowanym w wieku $25-35$ oraz 36-45 lat. Najmniej było seniorów w wieku powyżej 65 lat. Respondenci w zdecydowanej większości legitymowali się co najmniej wykształceniem średnim.

\section{Etap III}

Etap trzeci polegał na analizie zebranych informacji, przygotowaniu raportu końcowego i przeprowadzeniu warsztatów podsumowujących. Do udziału w warsztatach zaproszeni zostali przedstawiciele władz gmin objętych badaniem oraz tzw. lokalni liderzy, czyli osoby, które mają istotny wpływ na rozwój lokalny.

\section{Kluczowe wyniki}

Średni poziom zadowolenia z życia mieszkańców wszystkich analizowanych gmin wyniósł 3,86 . Osoby niezadowolone lub bardzo niezadowolone stanowiły niewiele ponad 3\% ankietowanych. Respondenci zadowoleni oraz bardzo zadowoleni stanowili zdecydowaną większość, tj. ponad $75 \%$ ogółu próby badawczej (zob. rys.1).

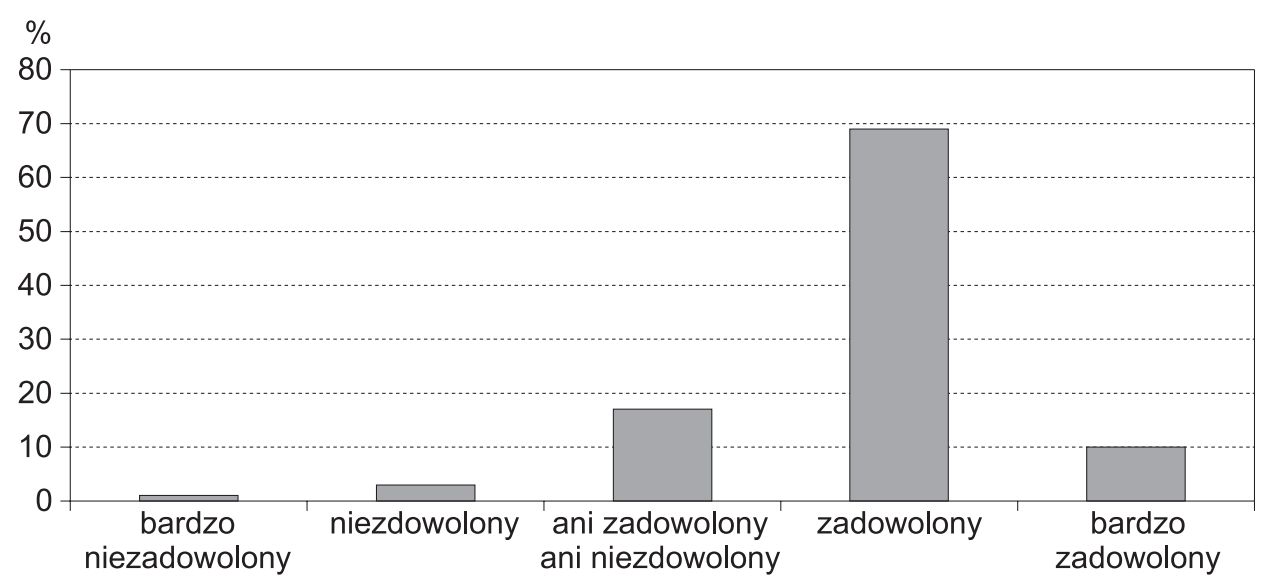

Rysunek 1. Rozkład odpowiedzi na pytanie dotyczące ogólnego poziomu zadowolenia z życia

Źródło: opracowanie własne na podstawie przeprowadzonych badań.

Badanie ujawniło występowanie znacznego zróżnicowania poziomu zadowolenia z życia wśród mieszkańców różnych gmin. Najniższy średni poziom satysfakcji z życia zadeklarowali mieszkańcy Wińska (średnia ocena = 3,51). Najwyższą satysfakcję z życia odnotowano w przypadku gminy Brzeg Dolny oraz Prochowice. W obu tych przypadkach średnia ocena zadowolenia z życia wyniosła 4,06. 
Wysoko oceniona została satysfakcja z wszystkich objętych badaniem dziedzin życia. Najwyższą średnią ocenę uzyskało zadowolenie z relacji z rodziną, znajomymi i sąsiadami (średnia $=3,98$ ). Na kolejnych miejscach znalazło się wykształcenie oraz zdrowie. Mieszkańcy badanego obszaru najmniej zadowoleni byli z możliwości spędzania wolnego czasu w swojej okolicy. Średnia ocena wyniosła w tym przypadku 3,12. Relatywnie nisko ocenili także własną sytuację materialną i zawodową oraz stan bezpieczeństwa. Średnie oceny przyznane poszczególnym dziedzinom życia zaprezentowano na rysunku 2.

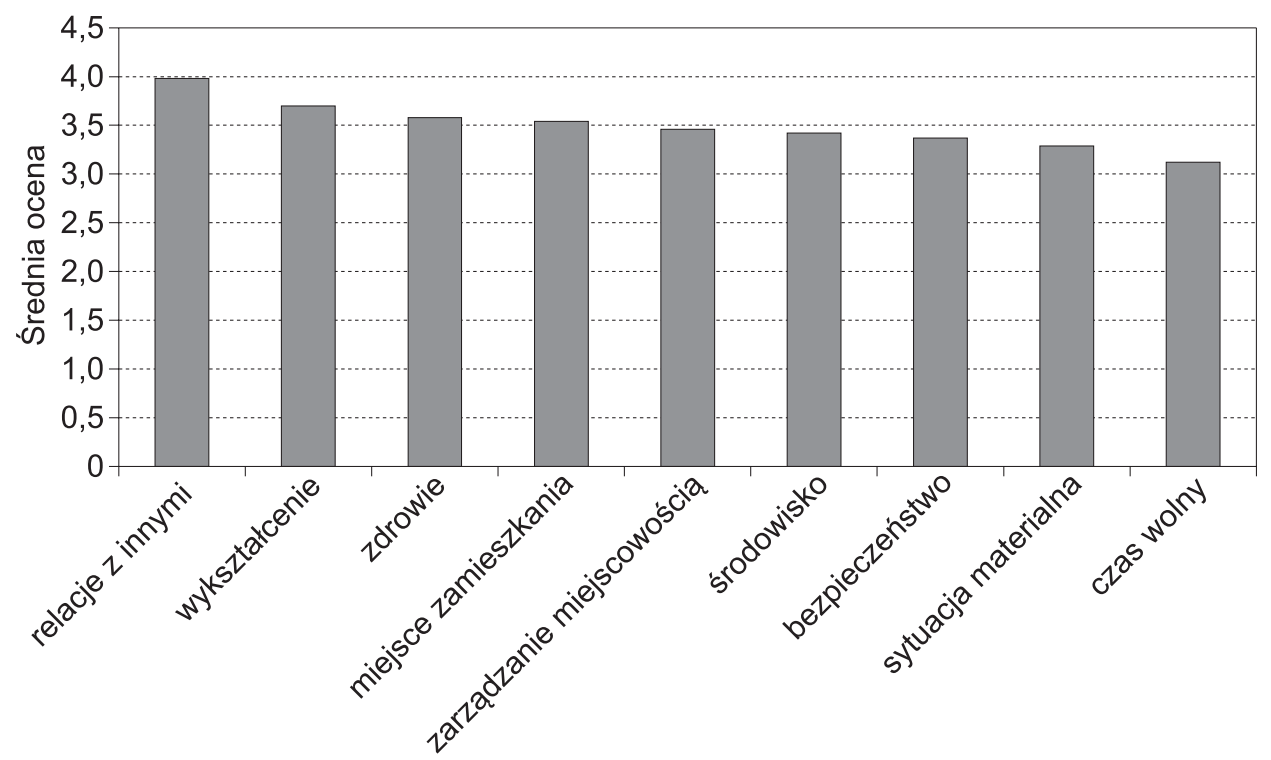

Rysunek 2. Średnia ocena zadowolenia z poszczególnych dziedzin życia

Źródło: opracowanie własne na podstawie przeprowadzonych badań.

Na podstawie zebranych informacji stwierdzić można, że osoby programujące rozwój badanego obszaru szczególną uwagę powinny zwrócić na zagadnienia dotyczące możliwości spędzania czasu wolnego, rozwój gospodarczy oraz poprawę bezpieczeństwa.

Do analizy ważności i stanu wyszczególnionych w kwestionariusz czterdziestu jeden czynników wykorzystano metodę Importance-Performance Analysis (zob. Riviezzo, de Nisco, Napolitano, 2009). Na rysunku 3 przedstawiono łączną ocenę znaczenia oraz stanu wszystkich czynników (każdy z nich oznaczony jest literą $\mathrm{k}$ wraz $\mathrm{z}$ odpowiednim numerem porządkowym). W pierwszej ćwiartce znalazły się te czynniki, które zdaniem respondentów są ważne, ale zadowolenie z ich stanu jest relatywnie niskie.

Można przyjąć, iż — zdaniem respondentów — są to kluczowe problemy badanego obszaru. Biorąc pod uwagę ograniczone zasoby, jakimi dysponują władze lokalne oraz regionalne, ich wysiłki powinny skoncentrować się na rozwiązaniu 
tych właśnie problemów. Znalazły się wśród nich zagadnienia wyszczególnione w ramach czterech następujących dziedzin życia:

1. Zdrowie i opieka zdrowotna - funkcjonowanie pogotowia ratunkowego (k 1.1).

2. Edukacja i wykształcenie - możliwość i warunki podnoszenia wykształcenia lub zmiany kwalifikacji przez osoby dorosłe (k 2.5).

3. Bezpieczeństwo publiczne i socjalne - bezpieczeństwo w ruchu drogowym (k 3.2). przygotowanie gminy na sytuacje kryzysowe — np. powódź, susza (k 3.3), brak wandalizmu i dewastacji w miejscach publicznych (k 3.4), opieka nad osobami starszymi (k 3.6) oraz pomoc dla osób i rodzin będących w trudniej sytuacji (k 3.7).

4. Sytuacja materialna i zawodowa (k 5.1), bezpieczeństwo zatrudnienia/ pewność utrzymania dotychczasowego źródła utrzymania (k 5.3) oraz zachowanie właściwych proporcji pomiędzy czasem pracy a czasem wolnym (k 5.5).

W ćwiartce drugiej znalazły się czynniki, które są ważne i ich stan jest wysoko oceniony; ćwiartka trzecia zawiera czynniki o mniejszym znaczeniu i wysokiej ocenie stanu, natomiast w ćwiartce czwartej ulokowane zostały czynniki o niskim znaczeniu i równocześnie niskiej ocenie stanu.

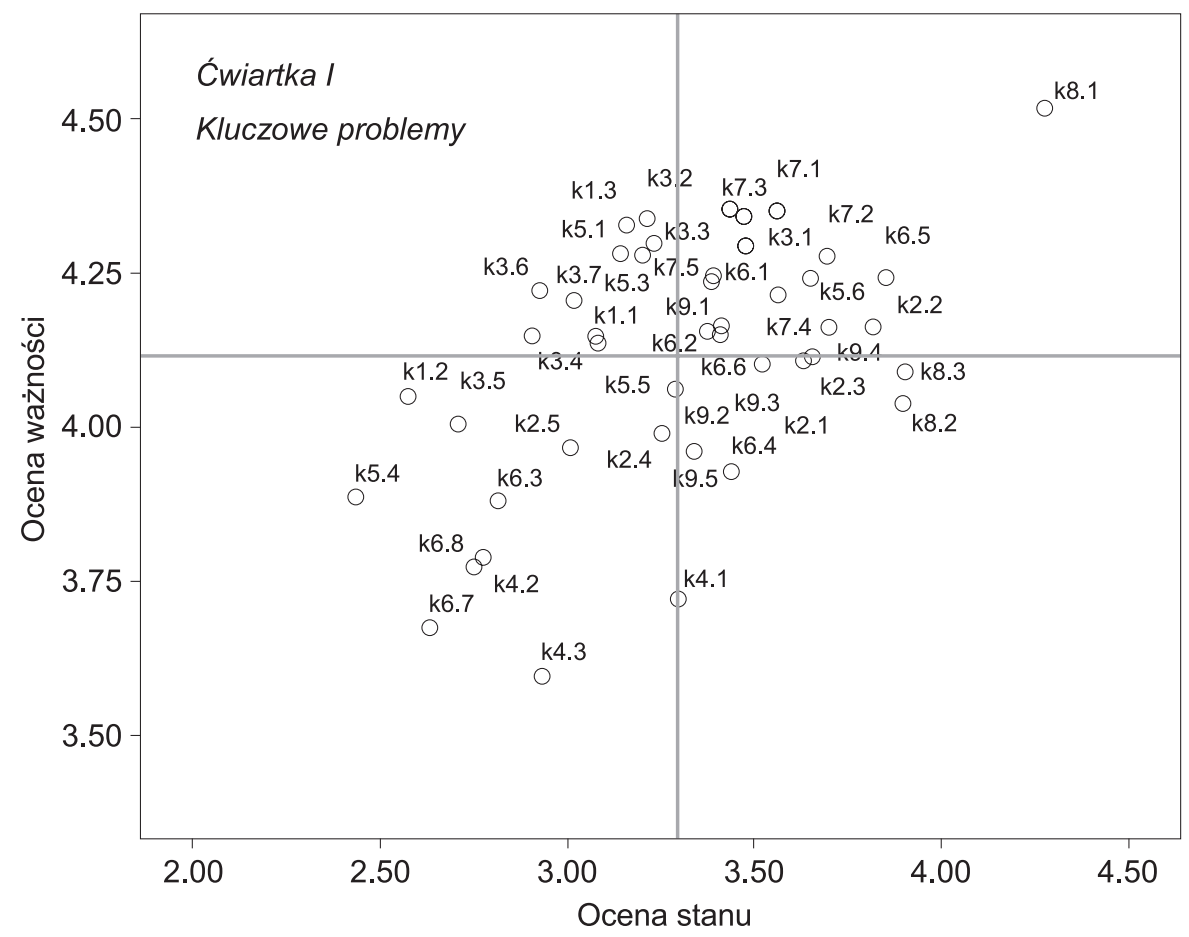

Rysunek 3. Ocena sytuacji i ważności

Źródło: opracowanie własne na podstawie przeprowadzonych badań. 
Analizując odpowiedzi uzyskane z drugiej części kwestionariusza, można stwierdzić, że choć zdaniem respondentów warunki życia w ich miejscowościach poprawiły się w ciągu ostatnich kilku lat, to nie uważają oni, że sami mają realny wpływ na to co się dzieje w ich otoczeniu. Nie są silnie związani z miejscem, w którym mieszkają. Średnia ocena stwierdzenia „nawet gdybym miał taką możliwość to nie chciałbym się przeprowadzić do innej miejscowości" wyniosła 2,94. Ponadto mimo iż twierdzą, że ich dochody nie są obecnie adekwatne do wykonywanej przez nich pracy, to jednak nie są zainteresowani zmianą miejsca pracy. Nie chcieliby także prowadzić własnej działalności gospodarczej. Średnia ocena stwierdzenia „,chciałbym otworzyć własną działalność gospodarczą” wyniosła zaledwie 2,15 .

\section{Wnioski}

Naturalną konsekwencją tendencji polegającej na coraz częstszym wyznaczaniu wysokiej jakości życia jako celu rozwoju lokalnego oraz regionalnego powinno być coraz większe zainteresowanie pomiarem jakości życia.

Zaprezentowany w artykule przykład pomiaru subiektywnej jakości życia potwierdza tezę, iż wyniki tego rodzaju badań mogą znaleźć zastosowanie na etapie przygotowywania strategii oraz programów rozwoju lokalnego i regionalnego. Mogą one zostać wykorzystane w ramach, zwykle w takich sytuacjach opracowywanej, diagnozy stanu, na przykład w celu zidentyfikowania kluczowych problemów danego obszaru. Mogą też być użyteczne w procesie formułowania celów rozwoju, a także priorytetyzacji zadań. Powinny być także wykorzystywane do oceny realizacji strategii i programów.

Ze względu na to, że nie ma jednej powszechnie przyjętej metody prowadzenia tego typu badań, warto sformułować zestaw kluczowych wniosków i rekomendacji wynikających z doświadczeń zdobytych podczas realizacji opisanego projektu:

1. Pomiaru subiektywnej jakości życia nie należy ograniczać jedynie do głównego jej wyznacznika, tj. do zadowolenia z życia. Sama informacja o poziomie zadowolenia mieszkańców z życia ma niską użyteczność z punktu widzenia podmiotów/osób odpowiedzialnych za rozwój.

2. Podczas badań należy uwzględnić poszczególne dziedziny oraz czynniki decydujące o jakości życia. Zdobyte w ten sposób informacje mogą być z powodzeniem wykorzystane $\mathrm{w}$ procesach podejmowani decyzji, np. podczas formułowania celów rozwoju oraz priorytetyzacji zadań itp.

3. Ocena poszczególnych czynników (komponentów jakości życia) powinna obejmować zarówno ich stan, czyli stopnień spełnienia oczekiwań, jak i ich znaczenie. Równoczesne uwzględnienie obu tych zmiennych pozwala zidentyfikować kluczowe problemy badanego obszaru, tj. takie, które są ważne i jednocześ- 
nie ich stan nie spełnia (albo spełnia na relatywnie niskim poziomie) oczekiwania respondentów.

4. Pełne korzyści z pomiaru subiektywnej jakości życia osiągnięte zostaną, gdy badania będą przeprowadzane cyklicznie z wykorzystaniem niezmiennej metody badawczej. Tylko zachowanie tych samych pytań umożliwi porównywalność uzyskiwanych wyników. Dlatego przed przystąpieniem do pierwszych badań warto poświęcić odpowiednio dużo czasu, aby właściwie zaprojektować badanie.

5. Wyzwaniem, którym warto byłoby się zająć w przyszłości, jest odróżnienie czynników, na które władze lokalne lub regionalne mają bezpośredni wpływ, od czynników, na które władze lokalne nie mają wpływu lub ich oddziaływanie jest niewielkie. Brak takiego rozróżnienia może zniechęcać władze do podejmowania wysiłków związanych z badaniem subiektywnej jakości życia, gdyż mogą one obawiać się przypisywania im odpowiedzialności za słabe wyniki w obszarach, które znajdują się poza ich bezpośrednim oddziaływaniem.

\section{Bibliografia}

Jakość życia w obszarze przygranicznym - wzmocnienie ponadgranicznych przepływów dla wspólnego zrównoważonego rozwoju planowania regionalnego (2014), red. T. Borys, R. Knippschild, Wrocław.

Jakość życia na poziomie lokalnym (2008), red. Borys T., Rogala P., Warszawa.

Czakon W. (2011), Zastosowanie studia przypadków w badaniach nauk o zarządzanie, [w:] Podstawy metodologii badań w naukach o zarządzaniu, red. W. Czakon, Warszawa.

Strategia rozwoju województwa dolnośląskiego 2020, (2014), Dolnośląski Urząd Wojewódzki, 1 maja 2016.

Kusterka-Jefmańska M. (2010), Wysoka jakość życia jako cel nadrzędny lokalnych strategii zrównoważonego rozwoju, „Zarządzanie publiczne” 14, nr 12.

Papuć E. (2011), Jakość życia - definicje i sposoby jej ujmowania, „Current Problems of Psychiatry" 2.

Riviezzo A., de Nisco A., Napolitano M.R. (2009), Importance-performance analysis as a tool in evaluating town centre management effectiveness, „International Journal of Retail \& Distribution Management" 9, nr 37.

Rogala P. (2013), Pomiar subiektywnej jakości życia jako przejaw dojrzałości w zarządzaniu jednostkami samorzadu, [w:] red. W. Skrzypek, Dojrzałość w odniesieniu do klientów i sfery ustug, Lublin.

Rogala P. (2014), In the serach for the method of quality of life evaluation, [w:] Challenges of sustainable development, red. W. Bartniczak, Rogala P., Wrocław.

Turska W., Skowron A. (2009), Metodyka oceny jakości życia, „Farmacja Polska” 8, nr 65.

\section{Źródła internetowe}

Urząd Miasta Legnicy (2015), Strategia rozwoju Legnicy 2015-2020 plus, 1 maja 2016, http:// www.portal.legnica.eu/legnica2/web/uploads/temp/pages/page_873/text_images/Strategia_ Rozwoju_Miasta_Legnicy_2015_2020_PLUS.pdf.

http://www.umwd.dolnyslask.pl/fileadmin/user_upload/Rozwoj_regionalny/SRWD/SRWD_2020-final.pdf.

Ekonomia - Wroclaw Economic Review 23/1 (2017)

(C) for this edition by CNS 